\title{
Retraction
}

\section{Retracted: Recent Advances in DENV Receptors}

\section{The Scientific World Journal}

Received 11 November 2013; Accepted 11 November 2013

Copyright (C) 2013 The Scientific World Journal. This is an open access article distributed under the Creative Commons Attribution License, which permits unrestricted use, distribution, and reproduction in any medium, provided the original work is properly cited.

This paper has been retracted as it is found to contain a substantial amount of material from a number of previously published papers. The three most plagiarized papers are (1) K. I. Hidari and T. Suzuki, "Dengue virus receptor," Tropical Medicine and Health, vol. 39, no. 4, supplement, pp. 37-43, 2011; (2) A. Cabrera-Hernandez and D. R. Smith, "Mammalian dengue virus receptors," Dengue Bulletin, vol. 29, no. 662, pp. 119-135, 2005; (3) A. Cabrera-Hernandez, C. Thepparit, L. Suksanpaisan, and D. R. Smith, "Dengue virus entry into liver (HepG2) cells is independent of hsp90 and hsp70," Journal of Medical Virology, vol. 79, no. 4, pp. 386392, 2007 (see [1]).

\section{References}

[1] S. Fang, Y. Wu, N. Wu, J. Zhang, and J. An, "Recent advances in DENV receptors," The Scientific World Journal, vol. 2013, Article ID 684690, 6 pages, 2013. 